\title{
Perkotaan Pasuruan Di Era Kolonial Belanda Pada Sekitar Abad XVIII s.d. XIX
}

\section{Muhammad Chawari}

Keywords: urban archaeology, history, settlement, trading, harbour, east java

\section{How to Cite:}

Chawari, M. (2002). Perkotaan Pasuruan Di Era Kolonial Belanda Pada Sekitar Abad XVIII s.d. XIX. Berkala Arkeologi, 22(1), 66-80. https://doi.org/10.30883/jba.v22i1.851

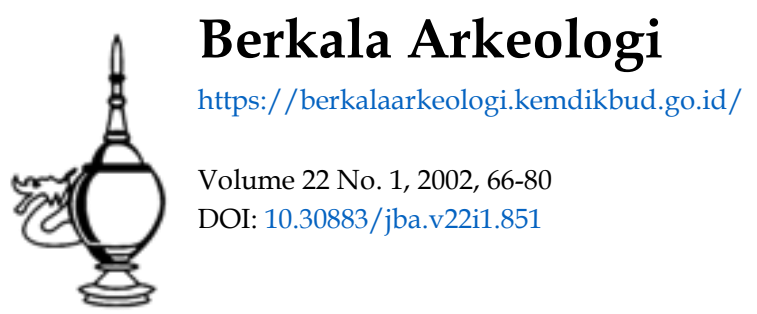

\section{c) (7) (2)}

This work is licensed under a Creative Commons Attribution-NonCommercial-ShareAlike 4.0 International License. 


\title{
PERKOTAAN PASURUAN DI ERA KOLONIAL BELANDA PADA SEKITAR ABAD XVIII s.d. XIX
}

\author{
Muhammad Chawari \\ (Balai Arkeologi Yogyakarta)
}

\section{Pengantar}

Tulisan ini dibuat berdasarkan hasil penelitian yang bertemakan Keletakan dan Bentuk Makam-makam Belanda Pada Kota-kota Pantai Tahap III yang dilaksanakan di tiga daerah tingkat II yaitu Situbondo, Probolinggo, dan Pasuruan. Pada sekitar abad XVIII s.d. XIX Situbondo, Probolinggo, dan Pasuruan pernah ikut berperan dalam panggung sejarah kebudayaan Indonesia. Di Ketiga daerah tersebut banyak dijumpai peninggalan-peninggalan arkeologis yang menunjukkan pengaruh asing, yaitu Eropa. Bangunan-bangunan berkarakteristik Eropa tersebut didominasi oleh bangunan Belanda. Keberadaan bangsa Belanda di Indonesia secara langsung maupun tidak langsung mempunyai pengaruh. Pengaruh tersebut meliputi berbagai segi kehidupan, termasuk di dalamnya budaya. Hal ini dapat dilihat antara lain pada munculnya bangunan-bangunan kolonial di berbagai kota, khususnya Pasuruan. Bangunan-bangunan tersebut dapat dibedakan menjadi bangunan-bangunan yang bersifat pribadi (misalnya bangunan rumah tinggal) dan bangunan-bangunan yang bersifat umum (misalnya bangunan kantor, gereja dll).

Sebelum kedatangan pengaruh kolonial, daerah Pasuruan telah berabad-abad didiami oleh orang-orang pribumi yang mempunyai kebudayaan cukup tinggi. Hal ini karena adanya pengaruh dari Kerajaan Majapahit, dan pada masa kemudian menjadi daerah pengaruh kekuasaan. Kerajaan Mataram Islam. Pada masa pengaruh kedua kerajaan tersebut, masuklah pedagang-pedagang asing, salah satunya Cina. Memang selain orang-orang pribumi, Cina, dan Belanda masih banyak pedagang-pedagang lain (baik lokal maupun asing) yang ikut meramaikan daerah Pasuruan. Masing-masing dari ketiga etnis tersebut (pribumi, Cina, dan Belanda) menempati lokasi tertentu, yang tidak sama. Orang-orang pribumi - yang karena selaku penduduk asli - menemapti hampir di seluruh pelosok Pasuruan. Sedangkan kelompok pendatang (Cina dan Belanda) menempati lokasi tertentu sesuai dengan kepentingannya masing-masing.

Dengan mengamati masing-masing kelompok etnis tersebut sesuai dengan ciri-ciri yang melekat padanya akan diketahui keberadaannya secara spesifik. Misalnya: keberadaan orang-oarng Cina dapat diketahui berdasarkan kekhususan bangunan tempat tinggal dan juga adanya klenteng sebagai tempat peribadatan mereka. Demikian juga dengan keberadaan orang-orang Belanda dapat diketahui berdasarkan keletakan bangunan Belanda serta adanya gereja sebagai tempat melaksanakan 
kegiatan ritualnya maupun benteng sebagai tempat pertahanan untuk mempertahankan eksistensinya. Dengan mengamati hal-hal tersebut akan dapat diketahui lokasi tempat tinggal mereka dalam kelompok-kelompok tertentu di suatu kota, khususnya Pasuruan.

\section{Pasuruan Sebelum Kedatangan Pengaruh Asing}

Sebelum kedatangan pengaruh asing, daerah-daerah di sekitar Pasuruan (termasuk Panarukan, Besuki, dan Probolinggo) merupakan pelabuhan-pelabuhan yang penting. Panarukan merupakan bandar yang penting dari Kerajaan Blambangan yang beberapa kali dikunjungi pedagang-pedagang Portugis (Tjiptoatmodjo, 1983).

Kemudian sebelum pengaruh Islam masuk ke Pasuruan, daerah ini (sering disebut dengan istilah Gembong) merupakan daerah yang paling lama dikuasai oleh raja-raja di Singasari yaitu Kerajaan Tumapel. Selanjutnya Pasuruan pada masa pengaruh Islam yaitu pada tahun 1535, yang ditandai dengan ditaklukannya daerah ini oleh Sultan Trenggana dari Demak. Penyerangan Demak terhadap Pasuruan mempunyai tujuan ganda, yaitu ingin secara langsung menguasai sekaligus menanamkan pengaruh Islam atas Pasuruan. Kedua, penaklukan Pasuruan merupakan batu loncatan untuk dapat menguasai Blambangan di ujung timur Jawa Timur. Hal ini dimungkinkan karena Pasuruan dianggap sebagai daerah perbatasan antara kerajaan-kerajaan di Jawa Timur bagian barat dengan kerajaan di ujung timur Jawa Timur.

Setelah Pasuruan menjadi daerah pengaruh Islam, maka Demak mengangkat seorang penguasa untnk memerintah Pasuruan. Nama dan asal usulnya penguasa Pasuruan yang telah kena pengaruh Islam tersebut tidak diketahui. Walaupun pemeritahan di Pasuruan merupakan kepanjangan tangan dari Kerajaan Demak, tetapi penguasa yang ada merupakan pemerintahan yang mandiri. Sehingga pada waktu Sultan Trenggana meninggal pada tahun 1546, pemerintahan di Pasuruan tidak mengalami atau menimbulkan keguncangan. Sehingga pada waktu pusat pengaruh Islam berpindah dari Demak ke Pajang, daerah Pasuruan masih loyal terhadap Islam. Hal ini ditunjukkan pada waktu Pajang ingin mengatasi ancaman dari raja-raja di ujung timur Jawa (Blambangan) yang belum Islam, raja di Pasuruan bersedia membantunya (Graaf, 1985).

Selanjutnya keadaan menjadi berubah, ketika pusat pemerintahan Islam pindah dari Pajang ke Mataram (Yogyakarta). Pada waktu itu Pasuruan tidak lagi berada dibawah kekuasaan Mataram. Sebab bersama-sama dengan Surabaya, Pasuruan mulai melawan Mataram. Hal ini ada indikasi bahwa antara penguasa di Pasuruan dan Surabaya masih ada hubungan keluarga. Oleh karena itulah pada masa Sultan Agnng, yang naik tahta 
pada tahun 1613, daerah Pasuruan dapat ditaklukkan oleh pasukan Mataram yang dipimpin Sultan Agung yaitu antara tahun 1616/1617.

Selanjutnya tata kota pada kerajaan-kerajaan bercorak Islam pada umumnya berpusat pada pusat pemerintahan yaitu kraton. Kraton yang dilengkapi dengan unsur-unsur pembentuk kota yang terdiri atas alun-alun, masjid agung, pasar, dan beberapa bangunan pendukung. Alun-alun sebagai tempat bertemunya antara rakyat dengan penguasa, sedangkan masjid sebagai tempat bertemunya antara hamba (rakyat dan penguasa) dengan sang pencipta, kemudian pasar sebagai tempat bertemunya seluruh fungsionaris pembentuk kota yaitu dalam hal perdagangan.

Unsur-unsur kota seperti tersebut di atas, sekarang ini masih dapat dilihat di Pasuruan. Memang di Pasuruan tidak dijumpai pusat pemerintahan yang berupa kraton, seperti di Yogyakarta, Surakarta, Cirebon, maupun Banten. Pusat pemerintahan lama yang ada hingga sekarang ini dan masih dipergunakan yaitu berupa kantor kabupaten. Kantor kabupaten dan sekaligus sebagai rumah dinas bupati merupakan bangunan lama yang antara lain terdiri atas pendopo dan dalem, yang keduanya berdiri di atas tanah yang cukup luas. Bangunan ini terdapat di pojok alun-alun sebelah timur laut. Kemudian masjid agung sebagai masjid "negara" selalu terdapat di sebelah barat alunalun.

Dengan demikian secara administratif pusat kotanya adalah yang sekarang dipakai untuk kantor bupati dengan alun-alun yang terdapat di Jalan Alun-alun Sebelah Utara. Kemudian Masjid Agung yang terletak di jalan Nusantara, ke utara sampai menembus perempatan yang kedua, ke kiri (barat) yaitu jalan Sukarno-Hatta. Di ruas jalan inilah terdapat pasar yang terletak di sebelah utara jalan Sukarno-Hatta tersebut.

\section{Pasuruan Masa Pengaruh Asing}

\section{A. Pasuruan Masa Pengaruh Cina}

Awal mula kedatangan orang-orang Cina di Jawa yaitu di Kerajaan Majapahit, terjadi pada abad XIV. Kemudian pada abad XV dan XVI para pedagang Cina (yang berasal dari Cina Selatan dan pesisir Vietnam (sekarang bernama Campa) semakin aktif di Jawa dan tempat-tempat lain di Nusantara. Bahkan pada abad XIV, para pedagang Cina tersebut sudah mempunyai daerah permukiman sendiri (pacinan) di beberapa kota pelabuhan di pantai utara dan di muara sungai-sungai besar di Jawa (Graaf, 1998).

Orang Cina adalah pemukim asing yang hampir selalu dijumpai di Jawa, bahkan sejak masa lampau. Permukiman Cina dapat dijumpai di berbagai kota kuna di Jawa, baik di 
kawasan pesisir maupun pedalaman. Pada umumnya, orang-orang Cina yang terdapat di berbagai kota di Jawa tersebut bergerak di bidang ekonomi, khususnya di sektor perdagangan (Kartodirjo, 1992; Abbas dan Enny Ratna Dewi, 1995). Artinya mereka berperan di sektor jasa yang menjembatani antara produsen dan konsumen, jarang sekali yang bergerak di bidang produksi. Kenyataan ini agak berbeda dengan yang terjadi di luar Jawa, di mana mereka juga terlibat di sektor produksi. Misalnya di Kalimantan Barat, orang-orang Cina sudah sejak dahulu terlibat di sektor produksi, di antaranya sebagai petani, penambang emas, atau perajin keramik (Wibisono, 1992).

Peran di sektor perdagangan tersebut di atas membuat mereka mampu mendominasi kehidupan ekonomi. Upaya untuk memperoleh kesejahteraan ekonomi tersebut didasari oleh kenyataan bahwa mereka adalah golongan minoritas di lingkungan tempat tinggal mereka yang baru, sehingga selalu berusaha untuk memperoleh rasa aman. Dengan kemampuan ekonomi, ada kalanya mereka dapat memperoleh "kedekatan" tertentu dengan penguasa (pribumi maupun kolonial) pada masanya (Kartodirdjo, 1992; Ricklefs, 1995). Pada masa kolonial bahkan terdapat stratifikasi sosial di dalam masyarakat, yaitu kalangan Eropa, Cina, dan pribumi (Widodo, 1988). Kedekatan orang-orang Cina dengan penguasa tersebut di antaranya dengan pemberian jabatan seperti syahbandar, tanda, maupun penganugerahan gelar kebangsawanan dari pihak kerajaan. Pada umumnya komoditi yang diperdagangkan oleh orang-orang Cina tersebut bermacam-macam, tergantung pada pasarnya. Kota dengan sifat pasar yang mempunyai prospek baik akan menarik banyak orang Cina untuk tinggal di daerah tersebut. Asumsinya adalah bahwa semakin tinggi kemampuan ekonomi suatu kota, maka semakin besar pula populasi orang-orang Cina yang terdapat di tempat itu (Abbas, 1998/1999).

Pada masa daerah ini dikendalikan oleh sebuah kekuasaan di bawah pengaruh Bupati Nitidiningrat atau Kyai Adipati Ario Nitidiningrat I (1751 - 1799) (Tjiptoatmodjo, 1983 dan Anonim, 2001), Pasuruan mengalami perkembangan yang cukup berarti. Dengan keadaan yang demikian ini segala potensi perdagangan juga mengalami hal yang sama. Hal inilah yang mengakibatkan masuknya pedagang-pedagang asing ke Pasuruan yang ditandai adanya kelompok permukiman orang-orang asing tersebut. Salah satu pedagang asing yang masuk ke daerah ini ini berasal dari etnis Cina. Pedagang-pedagang dari etnis Cina mula-mula datang ke daerah ini bertujuan untuk berdagang. Lama kelamaan mereka betah tinggal di Pasuruan, karena apa yang mereka usahakan dapat mengutungkan pribadi dan seluruh keluarganya maupun etnis Cina secara keseluruhan. Keberhasilan perdagangan orang-orang Cina di Jawa salah satunya berkaitan erat dengan materi (bahan) dan teknologi. Misal: adanya orangorang Cina yang berdagang dengan cara memperkenalkan kembang api (mencon) di keraton Majapahit pada pertengahan abad XV (Graaf, 1998). 
Secara umum kemunduran dan kehancuran kota-kota pelabuhan dagang di pantai utara Jawa salah satunya disebabkan adanya perkembangan politik internal di Jawa. Hal ini akibat munculnya dua kekuatan kerajaan di pedalaman Jawa, yaitu Pajang dan Mataram. Munculnya dua kekuatan yang waktunya berurutan tersebut mengakibatkan terhentinya perdagangan Cina di Jawa. Tetapi hal tersebut tidak mempengaruhi kekuatan VOC Belanda, sebab kedudukan Batavia pada abad XVII telah mantap, sehingga dapat mendukung kegiatan perdagangan kolonial Belanda di Jawa (Graaf, 1998).

\section{B. Pasuruan Masa Pengaruh Belanda}

Daerah Pasuruan di masa lampau merupakan kota pelabuhan yang sangat ramai. Kota tersebut pada waktu itu berada di bawah pengaruh kekuasaan Kerajaan Mataram Islam. Pada tanggal 11 November 1743 terjadi perjanjian antara Mataram dengan pihak Kompeni, masing-masing diwakili oleh Susuhunan Pakubuwana II dan Gubernur Jenderal van Imhoff. Perjanjian tersebut menetapkan bahwa Mataram harus menyerahkan semua daerah pesisir yang terletak di, sebelah timur yaitu mulai Surabaya, Pasuruan sampai dengan Probolinggo (termasuk bagian barat daerah Madura) (Lombard, 1996). Dengan demikian dapat dikatakan bahwa daearah-daerah tersebut merupakan batu loncatan bagi Kompeni dalam usahanya menaklukkan daerah-daerah di ujung timur pulau Jawa.

Kota-kota lama di Jawa sampai dengan abad XVIII tidak mengalami perkembangan yang berarti. Kota-kota yang tidak mempunyai fungsi perdagangan pada umumnya menjadi kota pusat pemerintahan daerah. Dari berbagai berita, cerita perjalanan, karya lukisan (gambar), bentuk kota kabupaten tidak jauh berbeda dengan lingkungan pedesaan sekitarnya. Rumah (dalem) bupati dan para pejabat tampak menonjol di sekeliling alun-alun, diselingi dengan rumah kontroler atau asisten residen dan perkantoran lain. Kelompok bangunan di kota lebih rapat satu sama lain dibandingkan dengan kelompok perumahan di pedesaan. Apabila dibanding dengan kota pantai kuna, kelompok perumahan di kota pusat pemerintahan lebih jarang. Bentuk bangunan rumah kebanyakan masih tradisional. Baru pada masa kemudian lambat laut muncul bangunan gedung (batu) yang berupa loji (vila). Dengan kehadiran orang-orang Eropa di kabupaten-kabupaten, berkat perluasan sistem pemerintahan kolonial yang lengkap dengan sistem birokrasinya, dan karena jarak negeri Belanda dengan Indonesia makin dekat akibat dibukanya Terusan Zues pada tahun 1870, wajah kota mulai berubah. Pusat kota kabupaten bertambah dengan bangunan baru, terutama gedung-gedung pemerintahan dan kediaman para pejabat pribumi dan Belanda (Soekiman, 2000).

Pedagang asing yang ikut meramaikan perdagangan di daerah Pasuruan selain dari etnis Cina seperti tersebut di atas adalah orang-orang Belanda. Daerah Pasuruan sebelum kedatangan pengaruh asing, semula merupakan pelabuhan tradisional yang 
tergolong cukup ramai. Orang-orang Belanda yang hadir di Indonesia (khususnya di Jawa) pada akhir abad XVI, semula bertujuan untuk berdagang semata. Lama kelamaan tujuan semula berubah, yaitu ingin menguasai sumber-sumber perdagangan tersebut. Penguasaan terhadap daerah-daerah tersebut diawali di daerah Pesisir Utara Jawa, kemudian ke seluruh Pulau Jawa dan Nusantara (Soekiman, 2000). Setelah berhasil menguasai daerah-daerah tersebut, maka selanjutnya berusaha untuk mempertahankannya dengan cara membuat pemerintahan baru di daerah yang dikuasai. Hal ini yang mendasari timbulnya kota-kota yang memiliki ciri-ciri asing (Belanda).

Selanjutnya adanya pemukiman orang-orang asing di Pasuruan pada abad XVIII antara lain disebutkan dalam Babad Kitha Pasuruan. Babad ini memberikan gambaran tentang Kota Pasuruan pada masa pemerintahan Bupati Nitidiningrat yang berkuasa pada sekitar pertengahan abad XVIII, yaitu sebagai berikut: Setelah itu sang nata (bupati) setiap hari mengadakan pengaturan kota. Jalan-jalan dibersihkan. Kampungkampung yang terdiri atas kampung Jawa, Cina, Madura, dan Belanda diatur menurut tempatnya masing-masing, sehingga menjadi indah dipandang. Nagari (kota) makin makmur dan terkenal hingga ke daerah lain. Karenanya banyak orang yang datang ke tempat tersebut bersama istri dan anak-anak mereka sambil membawa barang dagangan. Mereka kemudian berjualan dan memperoleh banyak keuntungan. Makin lama makin banyak orang yang datang, seperti orang Cina, Belanda, Mandar, Bawean, dan Bugis. Orang Sumbawa menjual kuda dan orang Belanda mendirikan loji (Tjiptoatmodjo, 1983).

Karesidenan Pasuruan pada waktu itu meliputi tiğa kabupaten, yaitu Pasuruan, Bangil, dan Malang, serta terbagi menjadi 12 distrik, yaitu:

\begin{tabular}{|c|l|c|}
\hline No. & \multicolumn{1}{|c|}{ Distrik } & Pal Persegi \\
\hline 01. & Kraton & 18 \\
\hline 02. & Kota & 10 \\
\hline 03. & Rajasa & 18 \\
\hline 04. & Winongan & 42 \\
\hline 05. & Keboncandi & 75 \\
\hline 06. & Jati & 17 \\
\hline 07. & Grati & 30 \\
\hline 08. & Melaten & 25 \\
\hline 09. & Gempeng & 58 \\
\hline 10. & Ngempit & 78 \\
\hline 11. & Tengger & 87 \\
\hline 12. & Wangkal dengan Porong & 135 \\
\hline \multicolumn{2}{|c|}{ Jumlah } & $\mathbf{5 9 3}$ \\
\hline
\end{tabular}


Sedangkan mengenai persebaran perkampungannya berdasarkan etnis pada tahun 1830 dapat digambarkan sebagai berikut: $\mathrm{Di}$ daerah dekat pantai terdapat perkampungan orang-orang Cina, Moor atau Arab. Di antara kelompok etnis-etnis tersebut, orang-orang Cina yang paling berpengaruh. Kegiatan perdagangan cukup ramai, sehingga di tepi pantai Bangil hingga Pasuruan bermukim ratusan pedagang dari Melayu, Bugis, dan Mandar. Sebagian besar orang Eropa (Belanda) di daerah Pasuruan tinggal di distrik Kota (329 jiwa), sedangkan di distrik Kraton ( 7 jiwa). Orang-orang Jawa bertempat tinggal di semua distrik, demikian juga dengan orang Madura yang terdapat di setiap distrik, kecuali di distrik Ngempit. Sejak tahun 1830 jumlah penduduk Karesidenan Pasuruan semakin meningkat. Hal ini terutama disebabkan karena adanya pembukaan tanah-tanah perkebunan di daerah tersebut yang menyerap banyak sekali pendatang dari daerah lain untuk menjadi tenaga kerja, seperti di perkebunan tebu dan kopi (Tjiptoatmodjo, 1983).

Perkembangan fisik kota (baik kota lokal tradisional maupun yang telah kena pengaruh asing atau kolonial) tidak jarang dipengaruhi atau dilatarbelakangi oleh faktor budaya setempat. Misal kota yang telah kena pengaruh Islam, budaya Islam tidak jarang ikut berperan. Demikian juga kota yang telah kena pengaruh asing, budaya asing tersebut ikut mempengaruhi. Pada masa kolonial Belanda, yang disebut kota Pasuruan mempunyai beberapa ciri-ciri fisiknya. Ciri-ciri fisik tersebut dapat dilihat dari konsetrasi bangunan-bangunan Belanda. Adapun bangunan-bangunan tersebut dapat dibedakan menjadi bangunan-bangunan yang bersifat pribadi (misalnya bangunan rumah tinggal) dan bangunan-bangunan yang bersifat umum (misalnya bangunan kantor, gereja, hotel, gudang, tempat rekreasi (taman kota) - tempat bersenang-senang - kamar bola -- sociteit dll). Dengan demikian unsur pembentuk kota Pasuruan pada masa kolonial mestinya harus berkaitan erat dengan bangunan-bangunan tersebut.

Berdasarkan penelitian dengan tema Keletakan dan Bentuk Makam-makam Belanda Pada Kota-kota Pantai Tahap III, di Kotamadia Pasuruan terdapat bangunan kolonial sebanyak 105 buah (Lihat Tabel. 1). Bangunan-bangunan tersebut sebagian besar terkonsentarsi pada 4 ruas jalan, yaitu Jalan Balai Kota, Jalan WR. Supratman, Jalan Veteran, dan Jalan Pahlawan. Sedangkan sebagian kecil tersebar di 14 jalan, yaitu Jalan Hasanudin, Jalan Pasar Ikan, Jalan Alun-alun Sebelah Timur, Jalan Alun-alun Sebelah Utara, Jalan Pelabuhan, Jalan Hayam Wuruk, Jalan Gadjah Mada, Jalan Panglima Sudirman, Jalam Sukarno - Hatta, Jalan Cemara, Jalan Wahidin Utara, Jalan Nusantara, Jalan Kartini, dan Jalan Anjasmara (Chawari, 2000: Lihat Tabel. 1). Dari ke-105 buah bangunan bercorak kolonial tersebut dapat dikelompokkan ke dalam 19 jenis bangunan (Lihat Tabel. 2).

Selanjutnya berdasarkan Tabel. 1 dan 2 serta peta lama diketahui bahwa Kota Pasuruan Lama (masa kolonial Belanda) berada di sepanjang Jalan Balai Kota ke selatan menembus Jalan Pahlawan dan di antara ke dua ruas jalan tersebut, ke barat 
yaitu Jalan WR. Supratman dan ke timur yaitu Jalan Veteran (terutama bagian barat). Hal ini dapat diketahui bahwa di Jalan Balai Kota mulai dari arah utara terdapat bangunan-bangunan penting yang berkaitan erat dengan ciri-ciri sebuah pusat kota. Bangunan-bangunan tersebut adalah Sekolah Teknik dan Kantor Balai Kota yang berada di sisi barat jalan tersebut. Sedangkan di sisi timur terdapat bangunanbangunan: Gereja Katolik Roma, Sekolah Eropa Tingkat 2, Hotel Morbeck, Kantor Residen, dan Hotel Marine. Selanjutnya ke arah selatan yaitu di Jalan Pahlawan di sisi barat terdapat bangunan-bangunan: Hotel Tonjas, rumah residen, dan rumah-rumah tinggal warga Belanda serta beberapa bangunan yang berfungsi sebagai perkantoran. Sedangkan di sisi timur jalan terdapat bangunan-bangunan Kamar Bola atau sociteit, Balai Penelitian Gula, Sekolah Eropa Tingkat 1, dan rumah-rumah tinggal warga Belanda. Antara Jalan Balai Kota dengan Jalan Pahlawan, ke arah barat terdapat Jalan WR. Supratman. Di Jalan WR. Supratman ini terdapat bangunan-bangunan: Hotel Centrum (sekarang menjadi Gereja Kristen Jawa dan beberapa rumah tinggal warga Belanda. Sedangkan ke arah timur terdapat Jalan Veteran, di mana di jalan ini terdapat beberapa bangunan yang semuanya merupakan rumah tinggal warga Belanda. Dari Jalan Pahlawan terus ke selatan yaitu pada Jalan Wahidin Utara terdapat Pabrik Gula.

Sementara itu, di ujung utara Jalan Balai Kota belok ke arah timur (kanan) yaitu pada Jalan Anjasmara terdapat Gereja GPIB - PNIEL. Dari Jalan Anjasmara tersebut ke arah barat lurus menembus Jalan Sukarno - Hatta terdapat beberapa bangunan yaitu: pasar lama, stasiun, dan gudang. Yang menarik - berdasarkan peta lama - diketahui adanya toko opium, di mana toko tersebut terletak tidak jauh dari pusat kota yaitu di Jalan Hayam Wuruk. Di daerah ini juga terdapat penjara yang terletak di Jalan Panglima Sudirman. Beberapa bangunan kolonial lainnya berada di Jalan Hasanudin. Di jalan ini terdapat sembilan bangunan, semuanya berfungsi sebagai rumah tinggal. Beberapa di antaranya yaitu tiga buah bangunan (merupakan bangunan campuran antara kolonial dengan Cina) merupakan milik keluarga Kwik - orang dari etnis Cina yang pernah ikut mengelola "de Bromo Machine Shops" (Chawari, 2000)

\section{Pasuruan Pada Masa Sekarang}

Nama Pasuruan dewasa ini terdiri atas dua daerah tingkat dua, yaitu Kotamadia Pasuruan dan Kabupaten Pasuruan. Secara geografis tulisan yang berkaitan dengan Perkotaan Pasuruan Di Era Kolonial Belanda ini hanya meliputi sebagian kecil dari Kotamadia Pasuruan saja, sebab Kabupaten Pasuruan letaknya mengelilingi Kotamadia Pasuruan, kecuali bagian utara - karena merupakan daerah pantai yaitu Selat Madura. Kotamadia Pasuruan sekarang ini mempunyai batas wilayah, yaitu sebelah utara merupakan daerah pantai (Selat Madura), daerah paling selatan terdiri atas Desa Pohjentrek, Desa Wirogunan, dan Desa Tembokrejo, Kecamatan Purworejo dan Desa Sekar Gadung, Kecamatan Bugul Kidul, daerah paling timur terdiri atas 
Desa Blandongan dan Desa Bakalan, Kecamatan Bugul Kidul, dan daerah paling barat terdiri atas Desa Karang Ketug, Desa Randusari, dan Desa Krapyakrejo, Kecamatan Gadingrejo atau berada di ujung paling barat Jalan Sukarno - Hatta (Chaldun, tt).

Dengan demikian jika batas-batas seperti tersebut di atas dibandingkan dengan batasbatas kota Pasuruan pada masa kolonial Belanda yaitu berdasarkan adanya konsentrasi bagunan Belanda akan terlihat bahwa Pasuruan pada sekitar abad XVIII s.d. XIX hanya merupakan bagian kecil dari wilayah yang ada pada saat ini. Sehingga dapat dikatakan bahwa Kotamadia Pasuruan dewasa ini telah mengalami perkembangan, terutama dari segi luasan wilayah administratif.

\section{Kesimpulan}

Di awal keberadaannya, Pasuruan merupakan kota tradisional yang berkembang akibat adanya pengaruh dari pusat-pusat budaya yang berkembang di sekitarnya. Pusat-pusat budaya tersebut antara lain Kerajaan Singasari, Kerajaan Blambangan, Kerajaan Majapahit, dan Kerajaan Mataram. Selain itu terdapatnya pelabuhan tradisional, yang berkembang karena adanya pedagang dari sekitar Pasuruan. Kota tradisional tersebut berpusat pada sebuah alun-alun dengan kantor bupati yang terletak di sebelah utara alun-alun. Selain adanya Masjid Agung yang terletak di sebelah barat alun-alun.

Selain pedagang lokal, juga terdapat pedagang asing. Pedagang-pedagang asing tersebut salah satunya adalah Belanda. Pedagang-pedagang Belanda tersebut kemudian menetap dan selanjutnya membuat koloni tersendiri sesuai dengan kepentingannya yaitu untuk mempertahankan eksitensinya. Dengan adanya pedagang asing yang menetap tersebut kemudian muncul permukimannya -- akhimya menjadi sebuah kota dengan segala fasilitas dan kelengkapannya.

Jika dilihat tata letak dan fasilitas antara kota tradisional maupun kota yang telah kena pengaruh kolonial Belanda tersebut terdapat beberapa perbedaan, antara lain:

1. Kota kolonial menempati areal di sebelah timur kota tradisional. Dengan demikian terjadi pergeseran lokasi.

2. Kota kolonial mempunyai fasilitas yang lebih lengkap untuk syarat sebuah kota dibanding kota tradisional. Kelengkapan atau fasilitas kota tersebut meliputi adanya bangunan-bangunan yang bersifat umum (misalnya bangunan kantor -Kantor Pos; Kantor Balai Kota; dan Kantor Residen, Stasiun Kereta Api, pasar, gereja -- GPIB dan gereja Katolik Roma, hotel -- Centrum; Morbeck; Marine; dan Tonjas, gudang, tempat rekreasi atau bersenang-senang -- kamar bola atau sociteit, juga adanya sekolah dengan berbagai ketingkatan -- Sekolah Teknik; Sekolah Pribumi; Sekolah Eropa Tingkat 1 dan 2 dll), selain tentunya bangunan-bangunan yang bersifat pribadi yaitu bangunan rumah tinggal. 


\section{KEPUSTAKAAN}

Abbas, Novida. 1998/1999. Laporan Hasil Penelitian Arekologi Permukiman Etnis Cina di Kota-kota Kuna Bercorak Islam di Jawa Tengah (Tahap II). Yogyakarta: Balai Arkeologi.

Abbas, N., \& Dewi, E. R. (1995). Perkembangan Kota Yogyakarta Berdasarkan Peningkatan Pemanfaatan Lahan. Berkala Arkeologi, 15(2), 25-34. https:// doi.org/10.30883/jba.v15i2.658

Anonim. 2001. Kabupaten Pasuruan Dalam Angka. Pasuruan: BAPPEDA Kabupaten Pasuruan dan BPS Kabupaten Pasuruan.

Chaldun, Achmad. Tt. Atlas Ilmu Pengetahuan Sosial Jawa Timur. Surabaya: PT. Karya Pembina Swajaya.

Chawari, Muhammad. 2000. Laporan Penelitian Arkeologi Keletakan dan Bentukbentuk Makam Belanda Pada Kota-kota Pantai (Tahap III). Yogyakarta: Balai Arkeologi.

Graaf, DR. H.J. De dan Pigeaud, DR. TH. G. TH. 1985. Kerajaan-kerajaan Islam di Jawa. Jakarta: Penerbit PT Grafiti Pers.

Graaf, DR. H.J. de dkk. 1998. Cina Muslim di Jawa Abad XV dan XVI Antara Historisitas dan Mitos. Yogyakarta: Penerbit PT Tiara Wacana.

Kartodirdjo, Sartono. 1992. Pengantar Sejarah Indonesia Baru: 1500-1900. Dari Emporium Sampai Imperium. Jakarta: PT. Gramedia Pustaka Utama.

Lombard, Denys. 1996. Nusa Jawa: Silang Budaya - Jaringan Asia. Buku. 2. Jakarta: Penerbit PT. Gramedia Pustaka Utama.

Ricklefs, M.C. 1995. Sejarah Indonesia Modern. Yogyakarta: Gadjah Mada University Press.

Soekiman, Prof, DR. Djoko. 2000. Kebudayaan Indis Dan Gaya Hidup Masyarakat Pendukungnya di Jawa Abad XVIII - Medio Abad XX. Yogyakarta: Penerbit Yayasan Bentang Budaya, Cetakan Pertama. 
Tjiptoatmodjo, F.A Sutjipto. 1983. Kota-kota Pantai di Sekitar Selat Madura (Abad XVII s.d. Medio Abad XIX). Yogyakarta: Disertasi pada Universitas Gadjah Mada.

Wibisono, Sonny. Chr. 1992. Emas di Kalimantan Barat: Kajian Etnohistori Untuk Arkeologi. PIA IV. Malang.

Widodo, Johannes. Chinese Settlement in a Changing City: An Architectural Study of the Urban Chinese Settlement in Semarang, Indonesia. Thesis. Leuven. Katholieke Universiteit. 
TABEL. 1. Bangunan Belanda di Kotamadia Pasuruan

\begin{tabular}{|c|c|c|c|c|}
\hline \multirow[t]{2}{*}{ No } & \multicolumn{2}{|c|}{ Letak Administratif } & \multicolumn{2}{|c|}{ Fungsi } \\
\hline & Jalan & No. & Dahulu & Sekarang \\
\hline 01. & Hasanudin & 1 & Rumah tinggal & Rumah tinggal \\
\hline 02. & Hasanudin & 2 & Rumah tinggal & Rumah tinggal \\
\hline 03. & Hasanudin & 4 & Rumah tinggal & Rumah tinggal \\
\hline 04. & Hasanudin & 6 & Rumah tinggal & Rumah tinggal \\
\hline 05. & Hasanudin & 7 & Rumah tinggal & Rumah tinggal \\
\hline 06. & Hasanudin & 9 & Rumah tinggal & Rumah tinggal \\
\hline 07. & Hasanudin & 10 & Rumah tinggal & Rumah tinggal \\
\hline 08. & Hasanudin & 11 & Rumah tinggal & Rumah tinggal \\
\hline 09. & Hasanudin & 12 & Rumah tinggal & Rumah tinggal \\
\hline 10. & Pasar Ikan & 94 & Gudang (?) & Gudang (?) \\
\hline 11. & Alun-alun seb. Timur & 1 & $\ldots$ & Telkom \\
\hline 12. & Alun-alun seb. Utara & 1 & Kantor Pos & Kantor Pos \\
\hline 13. & Alun-alun seb. Utara & 2 & Kantor Pos & Kantor Pos \\
\hline 14. & Alun-alun seb. Utara & 5 & Rumah tinggal Bupati & Kantor Walikota \\
\hline 15. & Alun-alun seb. Utara & 6 & Rumah tinggal Bupati & Kantor Walikota \\
\hline 16. & WR. Supratman & 1 & $\ldots$ & --- \\
\hline 17. & WR. Supratman & 2 & Hotel Centrum & Gereja Kristen Jawa \\
\hline 18. & WR. Supratman & 5 & Rumah tinggal & Rumah tinggal \\
\hline 19. & WR. Supratman & 7 & Rumah tinggal & Rumah tinggal \\
\hline 20. & WR. Supratman & 9 & Rumah tinggal & Rumah tinggal \\
\hline 21. & WR. Supratman & 10 & Rumah tinggal & Puskesman Kec. Kota \\
\hline 22. & WR. Supratman & 14 & Rumah tinggal & Rumah tinggal \\
\hline 23. & WR. Supratman & 18 & Rumah tinggal & Rumah tinggal \\
\hline 24. & WR. Supratman & 20 & Rumah tinggal & Rumah tinggal \\
\hline 25. & WR. Supratman & 24 & Rumah tinggal & Rumah tinggal \\
\hline 26. & WR. Supratman & 26 & Rumah tinggal & Rumah tinggal \\
\hline 27. & WR. Supratman & 28 & Rumah tinggal & Rumah tinggal \\
\hline 28. & WR. Supratman & 30 & Rumah tinggal & Rumah tinggal \\
\hline 29. & Balai Kota & 1 & Sekolah Teknik & Kantor Bank BCA \\
\hline 30. & Balai Kota & 1 & Gereja Katolik Roma & Gereja Katolik \\
\hline 31. & Balai Kota & 3 & -.. & $-\cdots$ \\
\hline 32. & Balai Kota & 4 & $-\cdots$ & $\ldots$ \\
\hline 33. & Balai Kota & 5 & $-\cdots$ & $-\cdots$ \\
\hline 34. & Balai Kota & 6 & $\ldots$ & $\ldots$ \\
\hline 35. & Balai Kota & 7 & Sekolah Eropa Tingkat 2 & SMP Negeri I \\
\hline 36. & Balai Kota & 8 & --- & --- \\
\hline 37. & Balai Kota & 9 & Hotel Morbeck & SMK II PGRI \\
\hline 38. & Balai Kota & 11 & Kantor Residen & Rumah Dan. Zipur \\
\hline 39. & Balai Kota & 12 & Kantor Bupati/Balai Kota & $\begin{array}{l}\text { Rumah Dinas } \\
\text { Walikota }\end{array}$ \\
\hline
\end{tabular}




\begin{tabular}{|c|c|c|c|c|}
\hline \multirow[t]{2}{*}{ No } & \multicolumn{2}{|c|}{ Letak Administratif } & \multicolumn{2}{|c|}{ Fungsi } \\
\hline & Jalan & No. & Dahulu & Sekarang \\
\hline 40. & Balai Kota & 14 & --- & --- \\
\hline 41. & Balai Kota & 16 & -.- & -- \\
\hline 42. & Balai Kota & 19 & Hotel Marine & $-\ldots$ \\
\hline 43. & Balai Kota & 21 & --- & --- \\
\hline 44. & Balai Kota & 23 & --- & $-\cdots$ \\
\hline 45. & Pelabuhan & 11 & --- & $-\cdots$ \\
\hline 46. & Pelabuhan & 12 & --- & -- \\
\hline 47. & Pelabuhan & 19 & --- & $\cdots$ \\
\hline 48. & Pelabuhan & 20 & $\cdots$ & $\cdots$ \\
\hline 49. & Pahlawan & 1 & Rumah tinggal & Rumah tinggal \\
\hline 50. & Pahlawan & 2 & Rumah tinggal & Kantor Sospol \\
\hline 51. & Pahlawan & 4 & Rumah tinggal & Kantor Sospol \\
\hline 52. & Pahlawan & 6 & -- & --- \\
\hline 53. & Pahlawan & 11 & Rumah tinggal & Rumah tinggal \\
\hline 54. & Pahlawan & 12 & $\cdots$ & --- \\
\hline 55. & Pahlawan & 15 & Rumah tinggal & Rumah tinggal \\
\hline 56. & Pahlawan & 16 & -- & --- \\
\hline 57. & Pahlawan & 17 & Rumah tinggal & Rumah tinggal \\
\hline 58. & Pahlawan & 18 & $\cdots$ & --- \\
\hline 59. & Pahlawan & 19 & Sociteit / Kamar Bola & STM-SPP Untung Srpt \\
\hline 60. & Pahlawan & 20 & --- & --- \\
\hline 61. & Pahlawan & 21 & Rumah tinggal & Rumah kosong \\
\hline 62. & Pahlawan & 22 & $\cdots$ & -.- \\
\hline 63. & Pahlawan & 23 & $-\cdots$ & $\ldots$ \\
\hline 64. & Pahlawan & $\cdots$ & Hotel Tonjas & Taman Kota \\
\hline 65. & Pahlawan & 25 & Balai Penelitian Gula & $\begin{array}{l}\text { Pusat Penelitian } \\
\text { Perkebunan Gula } \\
\text { Indonesia = P3GI }\end{array}$ \\
\hline 66. & Pahlawan & 26 & Rumah tinggal Residen & Kantor DPRD Kodia \\
\hline 67. & Pahlawan & 27 & --- & Mess P3GI \\
\hline 68. & Pahlawan & 31 & $-\cdots$ & Mess P3GI \\
\hline 69. & Pahlawan & 33 & $-\cdots$ & Mess P3GI \\
\hline 70. & Pahlawan & 35 & $\cdots$ & Mess P3GI \\
\hline 71. & Pahlawan & 36 & $\cdots$ & $\ldots$ \\
\hline 72. & Pahlawan & 38 & $\ldots$ & -- \\
\hline 73. & Pahlawan & 39 & --- & $-\cdots$ \\
\hline 74. & Pahlawan & 40 & Rumah tinggal & Rumah tinggal \\
\hline 75. & Pahlawan & 41 & --- & --- \\
\hline 76. & Pahlawan & 42 & Rumah tinggal & Rumah tinggal \\
\hline 77. & Pahlawan & 43 & $-\cdots$ & --- \\
\hline 78. & Pahlawan & 44 & Rumah tinggal & Rumah tinggal \\
\hline 79. & Pahlawan & 45 & $\ldots$ & --- \\
\hline
\end{tabular}




\begin{tabular}{|c|l|c||l|l|}
\hline \multirow{2}{*}{ No } & \multicolumn{2}{|c|}{ Letak Administratif } & \multicolumn{2}{c|}{ Fungsi } \\
\cline { 2 - 5 } & \multicolumn{2}{|c|}{ Jalan } & No. & \multicolumn{2}{c|}{ Dahulu } & \multicolumn{1}{c|}{ Sekarang } \\
\hline 80. & Pahlawan & 47 & \multicolumn{1}{c|}{-.- } & \\
\hline 81. & Pahlawan & 49 & Sekolah Eropa Tingkat 1 & Sekolah Dasar \\
\hline 82. & Pahlawan & 51 & \multicolumn{1}{c|}{---} & \\
\hline 83. & Pahlawan & $53 \mathrm{~A}$ & Rumah tinggal & Rumah tinggal \\
\hline 84. & Pahlawan & 53 & Rumah tinggal & Rumah tinggal \\
\hline 85. & Pahlawan & 55 & Rumah tinggal & Rumah tinggal \\
\hline 86. & Hayam Wuruk & 11 & Toko Opium & \\
\hline 87. & Hayam Wuruk & 13 & Toko Opium & $\cdots$ \\
\hline 88. & Gajah Mada & 26 & Rumah tinggal & Rumah tinggal \\
\hline 89. & Gajah Mada & 49 & Rumah tinggal & Rumah tinggal \\
\hline 90. & Gajah Mada & 55 & Rumah tinggal & Rumah tinggal \\
\hline 91. & Panglima Sudirman & 1 & Penjara & Penjara \\
\hline 92. & Sukarno - Hatta & --- & Pasar & Pasar \\
\hline 93. & Sukarno - Hatta & --- & Stasiun Kereta Api & Stasiun Kereta Api \\
\hline 94. & Sukarno - Hatta & 23 & Gudang Kapuk & Asrama Zeni Tempur \\
\hline 95. & Sukarno - Hatta & --- & Gudang Kapuk & Asrama Zeni Tempur \\
\hline 96. & Cemara & 21 & Rumah tinggal & Rumah tinggal \\
\hline 97. & Cemara & 43 & Rumah tinggal & Rumah tinggal \\
\hline 98. & Veteran & 2 & Rumah tinggal & Rumah tinggal \\
\hline 99. & Veteran & 4 & Rumah tinggal & Rumah tinggal \\
\hline 100 & Veteran & 6 & Rumah tinggal & Rumah tinggal \\
\hline 101 & Veteran & 10 & Rumah tinggal & Rumah tinggal \\
\hline 102 & Veteran & 12 & Rumah tinggal & Rumah tinggal \\
\hline 103 & Veteran & 14 & Rumah tinggal & Rumah tinggal \\
\hline 104 & Wahidin Utara & 18 & Pabrik gula & Gudang (?) \\
\hline 105 & Wahidin Utara & 20 & Pabrik gula & Gudang (?) \\
\hline 106 & Wahidin Utara & 22 & Pabrik gula & Gudang (?) \\
\hline 107 & Wahidin Utara & 24 & Pabrik gula & Gudang (?) \\
\hline 108 & Nusantara & --- & Rumah tinggal Wedono & Rumah Sakit Bersalin \\
\hline 109 & Kartini & --- & Sekolah pribumi & SMP III \\
\hline 110 & Anjasmara & --- & Gereja Kristen & Gereja GPIB PNIEL \\
\hline & & & & \\
\hline
\end{tabular}


TABEL. 2. Jenis Bangunan Belanda di Kotamadia Pasuruan

\begin{tabular}{|c|l|c|c|}
\hline No. & \multicolumn{1}{|c|}{ Jenis Bangunan } & Jumlah & Keterangan \\
\hline 01. & Kantor Residen & 1 & --- \\
\hline 02. & Rumah Tinggal Residen & 1 & --- \\
\hline 03. & Kantor Bupati & 1 & --- \\
\hline 04. & Rumah Tinggal Bupati & 2 & Sekarang dengan 2 nomor \\
\hline 05. & Rumah Tinggal Wedono & 1 & --- \\
\hline 06. & Stasiun Kereta Api & 1 & --- \\
\hline 07. & Pasar & 1 & --- \\
\hline 08. & Hotel & 4 & --- \\
\hline 09. & Kantor Pos & 2 & Sekarang dengan 2 nomor \\
\hline 10. & Sekolah & 4 & --- \\
\hline 11. & Rumah Tinggal & 44 & --- \\
\hline 12. & Gereja & 2 & --- \\
\hline 13. & Sociteit (Kamar Bola) & 1 & --- \\
\hline 14. & Gedung Penelitian Gula & 1 & --- \\
\hline 15. & Toko Opium & 2 & --- \\
\hline 16. & Gudang & 3 & --- \\
\hline 17. & Pabrik Gula & 4 & Sekarang dengan 4 nomor \\
\hline 18. & Penjara & 1 & --- \\
\hline 19. & Belum diketahui & 34 & \\
\hline \hline & \multicolumn{1}{|c|}{ Jumlah } & 110 & \\
\hline
\end{tabular}

